\title{
PREFACE: TECHNICAL COMMISSION I
}

\author{
Stefan Hinz ${ }^{1}$, Raul Queiroz Feitosa ${ }^{2}$, Martin Weinmann ${ }^{1}$, Boris Jutzi ${ }^{1}$ \\ ${ }^{1}$ Karlsruhe Institute of Technology, Kaiserstraße 12, 76131 Karlsruhe, Germany \\ ${ }^{2}$ Department of Electrical Engineering, Pontifical Catholic University of Rio de Janeiro, Rio de Janeiro, Brazil
}

For ISPRS Technical Commission I (TC I), 76 submissions for the 2021 Congress edition of ISPRS Annals and ISPRS Archives were received. This included both full paper and abstract submissions from all over the world. Continuing the success of double blind paper reviewing in preparation of the 2016 Prague congress, the 2018 Karlsruhe symposium as well as the 2020 edition of the ISPRS congress, also this time, TC I organized a strict peer-reviewing process. This included double-blind reviewing for full papers as well as a two-stage evaluation of abstract submissions - first stage based on the submitted abstracts ("conditional acceptance"), and second stage after submission of the respective final papers.

For the 2021 edition of the ISPRS congress, we received 32 full paper submissions and 46 abstract submissions, which underlines the trend towards full paper submissions compared to previous TC I events.

17 full papers passed the double-blind peer-review process and were accepted for publication in the ISPRS Annals (acceptance rate 53\%); none of the papers was reviewed by less than two reviewers; for the majority of full papers, three or four reviews were obtained. Abstract submissions and their respective final papers were reviewed by a team of professionals. In total, 28 papers were accepted to the ISPRS Archives.

Strict peer-reviewing relies on many voluntary reviewers spending their time for reading and evaluating the submissions. We would like to express our thanks to our reviewing team - especially since they were again willing to contribute to the review process just after completion of the 2020 edition of the ISPRS congress:

$\begin{array}{lll}\text { Costas Armenakis } & \text { Petra Helmholz } & \text { Daniela Poli } \\ \text { Krzysztof Bakula } & \text { Ludwig Hoegner } & \text { Rongjun Qin } \\ \text { Timo Balz } & \text { Patrick Hübner } & \text { Yuchu Qin } \\ \text { Daniele Cerra } & \text { Dorota Iwaszczuk } & \text { Peter Reinartz } \\ \text { Kai-Wei Cheng } & \text { Karsten Jacobsen } & \text { Ralf Reulke } \\ \text { Filiberto Chiabrando } & \text { Konstantinos Karantzalos } & \text { Petri Rönnholm } \\ \text { Ismael Colomina } & \text { Marco Körner } & \text { Michael Schmitt } \\ \text { Michael Cramer } & \text { Ville Lehtola } & \text { Jan Skaloud } \\ \text { Michele Crosetto } & \text { Andrea Lingua } & \text { Julian Smit } \\ \text { Naser El-Sheimy } & \text { Andrea Masiero } & \text { Emmanuelle Vaudour } \\ \text { Jean-Baptiste Féret } & \text { Rupert Mueller } & \text { Teng Wang } \\ \text { Craig Glennie } & \text { Stephan Nebiker } & \text { Cheng Wang } \\ \text { José Goncalves } & \text { Francesco Nex } & \text { Michael Weinmann } \\ \text { Görres Grenzdörffer } & \text { Anthony Pamart } & \text { Chenglu Wen }\end{array}$

Thank you so much!

The manuscripts in both the ISPRS Annals and Archives cover a broad range of topics related to remote sensing platforms, technologies, systems and related methods and reflect the current trends in algorithmic research and developments in sensing and data acquisition methods. Noteworthy is that numerous contributions were again submitted to Intercommission WGs of TC I with TC II and TC IV, which underlines the continuing trend towards an integral approach to sensors, systems and methods in photogrammetry, remote sensing and mobile mapping. 